\title{
Factors Affecting Young Customers' Saving Intention: An Integrative Review in Sri Lankan Context
}

\author{
W.M.K.T. Dharmarathna a, * (D), D.A.T. Kumari b \\ a MBA Student, Wayamba University of Sri Lanka. \\ b Department of Banking and Finance, Wayamba University of Sri Lanka, Kuliyapitiya-60200, Sri Lanka. \\ *Corresponding author email: kaveeshat60@ymail.com \\ DOI: https://doi.org/10.34256/ajir2121
}

Received: 26-02-2021

Revised: 21-03-2021

Accepted: 28-03-2021

Published: 12-04-2021

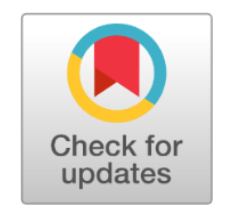

\begin{abstract}
Savings in banks or any other financial institution will be a key factor in raising the capital of any economy in the world. It will boost the economic growth when there is a higher savings portfolio in an economy. As a developing country, Sri Lanka looks forward to expanding the economy through the financial system to invest in development programs to mitigate financial shortages. The Central Bank of Sri Lanka is the principal financial institution that controls and oversees the entire financial system of the country through a variety of banking and financial institutions. The Sri Lankan financial system can be categorized as the banking sector, the non-bank finance and leasing sector, key traders, the micro-credit sector and the money brokerage industry. The banking industry in the financial system plays a major role in attracting client's savings into the economy. Savings can be regarded as income for one person as well as an investment for future benefits. In this paper concentrating mainly on the savings intention of young people or clients in the Licensed Specialized Banks and affecting the factors concerning their intention to save. This study will pay attention on the impact of factors on savings intention of young customers in the given population to identify which factors have more or less effects on each factor. Identifying the impact of each is important to generalize the results of research virtually into the actual working environment. This will be useful for policy-makers, decision-makers or banking strategists to implement new plans and even alter their vision statements.
\end{abstract}

Keywords: Financial Literacy, Financial Benefits, Personal income, Peer influence, Self-control, Savings Intention

\section{Introduction}

Increasing saving habit among the people in the society is very important for any economy as it fulfill capital requirements for the ongoing development. The habit of saving comes from the long history in the world from England where people used to keep their gold as repositories in the possession of silversmiths. Later, with many changes in the global economy, banks were launched in many countries to manage deposits and investments from people providing advantages against their deposits. It was declared $31^{\text {st }}$ October 1924 as World Savings Day at the 1st International Congress of the Savings Bank in Milan. However, people are needed to save this surplus money for certain reasons. This has been explained as grounds for public demand for money. The first is transactions demand, 
second precautionary demand and the speculative demand. More people are managing their savings on these motives as explained by the John Menard Keynes in his "general theory".

The Sri Lankan financial system can be categorized as the banking sector, the nonbanking finance and leasing sector, key traders, the micro-credit sector and the money brokerage industry (CBSL, 2019).It comprises the major financial institutions, namely the Central Bank of Sri Lanka (CBSL), Licensed Commercial Banks (LCBs), Licensed Specialised Banks (LSBs), Licensed Finance Companies (LFCs), Specialised Leasing Companies (SLCs), Primary Dealers (PDs), Pension and Provident Funds, Insurance Companies, Rural Banks, Stock Brokers, Securities Market Intermediaries, Unit Trusts and Thrift and Credit Co-operative Societies; the major financial markets, such as the Foreign Exchange Market, Money Market, Capital Market and the informal financial market; and the financial infrastructure which is the legal framework related to the financial system and the payment and settlement. The banking sector in the financial system plays a major role in attracting customers' savings in the economy. In the banking sector there are two types of banks can be identified as licensed commercial Banks (LCBs) which have 26 banks in numbers in Sri Lanka and Licensed Specialized Banks (LSBs) which have 6 banks in numbers in this category (CBSL., 2020). Those are National Savings Bank (NSB), Sri Lanka Savings Bank (SLSB), Housing Development Finance Corporation Bank (HDFC), State Mortgage and Investment Bank(SMIB), Regional Development Bank (RDB) and Sanasa Development Bank(SDB). Here we can identify state owned banks on the other side and private banks both within the banking system. However, the banking sector is expanding its portfolio of assets by LKR 9,619 billion in licensed Commercial Banks (BCL) and LKR 1,449 billion in Licensed Specialized Banks (SBL). When consider Sri Lankan financial system Licensed Specialized Banks are operating under special regulatory framework imposed by the Central bank with functions such as savings and loans for medium and small entrepreneurs in rural areas of the country. In comparison with licensed commercial banks, savings or the asset base are much lower in the specialized banking sector. There may be many factors that affect the reduction of savings in these banks as opposed to other commercial banks. In modern society, all levels of people, such as children, adolescents, youth and the elderly are committed to any financial institution in the country. In this context, people are accustomed to choosing their banking institution on many factors for their savings or any other banking business.

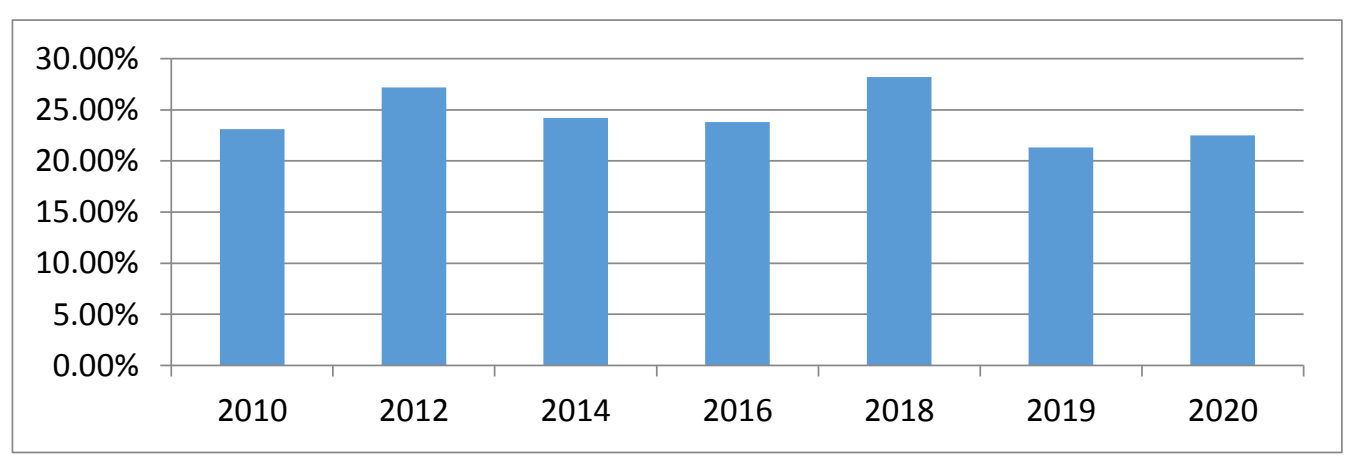

Figure 1. Sri Lanka Household Saving Ratio

Source: Annual report (Central Bank of Sri Lanka 2019) 
Accordingly, the deposit base or the saving base will be shared among these banks on preferred factors of the people and it will grow the total asset of the bank and also may fluctuate time to time with the competition to attract the savings by these institutions on their competitive advantages. In this paper concentrating mainly on the savings intention of young people or clients in the Licensed Specialized Banks discussed above and affecting the factors concerning their intention to save. Here, the young population (18 - 30 years) will be selected among the total customer population in specialized banks in Sri Lanka. The gross household saving rate in Sri Lanka is currently fluctuating at $22.5 \%$ by 2020 versus $21.5 \%$ in the last quarter (tradingeconomics.com). The saving behavior of the Sri Lankan people changes from time to time (Figure 1).

As figure 1 shows the personal savings of Sri Lanka is significantly increasing in 2018 and declining in 2020. However when analyze current savings portfolio of Sri Lanka it is evident that Licensed commercial banks holding nearly $89 \%$ and Licensed Specialized banks holding nearly $11 \%$ from the total savings. Here it is clear that the specialized banks (7 Banks) have very lower saving portfolio in Sri Lankan Banking system.

In identifying the above, it is more important to focus on customer savings intentions for specialized banks and the factors that have impacted savings at these banks. In the purpose of finding impact of factors on the savings intention in specialized banks it is important to select specific geographical area and the specific customer base for the convenient of the researcher. As an analytical research here the main focus will be on the region Central Province of Sri Lanka and there licensed specialized banks. It was well known factor that young generation of the country is very keen on modern banking facilities and accordingly they are switching. However mostly young age population has a very lower level of commitments with the LCBs in Sri Lanka. This commitment would be out of $11 \%$ of the household savings base only $4 \%$ is representing the young customer base in this banking sector. Therefore, this research will be based on and carried out based on the opinions and feedback from young customers in the region on their intensity to save in specialized banks. In this context, it is possible to know which factors have the most impact on young intensive clients. Weather the Personal Income or Financial Benefits or Financial literacy or parental socialization or peer influence or selfcontrol over the gender factor will be the higher or lower impact on the savings intention of young customers in the central province.

\section{Banks as a facilitating institution for public savings}

Banks are the major type of deposit taking institution; they make their living predominantly by taking deposits which represent their liabilities and loaning these funds to borrowers which represent their assets. They lend money at a higher interest rate than the funds, and the difference is their gross margin before spending and taxes. In addition, banks can earn commissions and fees by selling various products such as foreign exchange services, safe custody services, advice, account management charges, credit card facilities, insurance and so forth. Banks and various financial institutions exist to offer intermediation services. Various financial products are available in the market, and they differ in terms of risk associated and return they offer; also duration of financial products vary (Bonga, \& Mlambo, 2016).

The bank is an institution that handles cash and credit. It takes deposits from the public and provides loans and advances to those who require funds for a variety of reasons. The bank is an activity that implies the 
acceptance of deposits for loan or investment purposes. Providing such basic financial services such as savings, payments and credit can bring about a significant positive change in poor people's lives (Aggarwal, 2014). Besides accepting deposits and loan funds, the bank also involves the provision of various other services as well as its major banking business. They are primarily agency services, but there are also several general services. Bankers are those who undertake banking activities, take deposits and lend money for different purposes.

Hart (1994) defined a banker or bank as a person or a company carrying on the business of receiving money, collecting drafts, for customers' subject to the obligation of honoring cheques drawn upon them from time to time by the customers to the extent of the amounts available on their current accounts.

There is no statutory definition of a banker's customer, and so one has to refer to the decisions of the courts in order to discover the principles which determine whether or not a person is a customer. In the United States, Sect. 4-104 (1) (e) 1957 of the Uniform Commercial Code defines as "any person having an account with a bank or for whom a bank has agreed to collect items and includes a bank carrying an account with another bank". In the words of Lord Davey in Great Western Railway Co. V. London and County Banking Co. Ltd., in 1901, "there must be some sort of account, whether a deposit or a current account or a similar relationship, to make a man a client of a banker".

Role of banks: The functions of banks are divided into two categories: primary and secondary functions, including branch services.
The banks' main functions are to take deposits and lend money. The banks' primary activity is to activate public deposits. People who have excess income and savings find it convenient to deposit the money at the banks. The second major function of banks is the provision of loans and advances. These loans and advances are made to members of the public and the business community at an interest rate higher than that allowed by banks on various deposit accounts.

Historically, Sri Lanka's financial system has been characterised as one of the financial systems with a predominant banking sector. The Central Bank of Sri Lanka (CBSL) is the only regulator of the Sri Lankan banking system. Moreover, as illustrated in table 1, the composition of the financial system and the relative importance of each component in the financial system have not changed in the recent past though there are significant changes in the banking system structure.

The banking sector continues to be the dominant player in the financial system accounting for around 71.6 percent (including percent held by the CBSL) of the total assets as of 2019. In addition, Licensed Commercial Banks (CBLs) dominate the banking system with about 75 per cent of assets in the banking system, where the two largest CBLs are held by the State. There are currently 32 deposit-taking banks in Sri Lanka, 26 of which are Licensed Specialized Banks (CBLs) and 6 of which are Licensed Specialized Banks (LSB) in which national savings bank and Sri Lanka Savings bank merged together in 2020 as a single bank. As far as ownership is concerned, 13 are local LBCs, while 13 other LBCs are foreign bank branches (Table 2).

Table 1. Total asset of banking sector (Comparison of 2010 and 2019

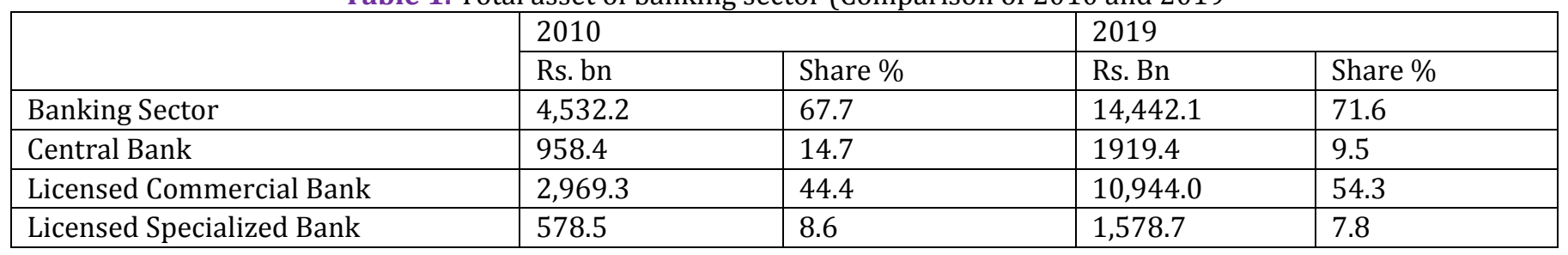


The three largest deposit collectors are state-owned banks, which together represent about 56 per cent of deposits mobilized by the banking system. Nevertheless, the share held by state-owned banks (in total assets) was reduced to $45,9 \%$ in 2020 compared with 58,2 $\%$ in 2010 . In addition, the two publicly funded development-oriented financial institutions (i.e. Housing Development \& Finance Corporation and State Mortgage \& Investment Bank) mainly deal with long-term development finance needs that are not fulfilled by commercial banks and other long-term credit requirements for agricultural, housing and construction sectors. State-owned National Savings Bank (NSB), the largest LSB, is mainly concerned with servings of small scale savers. The NSB is one of the government's main tools for implementing its interest rate policy, whereas the majority of the funds raised by the NSB are held in government securities. For example, NSB had about $74 \%$ of its funds in government financial instruments by the end of 2019.

\section{Saving Intention}

The saving of a country is very important to its economic growth as well as development in every time as it is providing the capital for investment and drive the development and growth of the economy (Kumari 2012a; 2012b; 2013). This 'Savings' has been explained in various studies by various definitions of economists, socialists and many more philosophers. The saving intension can influence the saving behavior of individuals. (Umi Widyastuti et al., 2016). The speed of economic growth is determined by the ability to save because high savings rate will drive up the rate of investment and consequently stimulate economic growth (CM Thung et al., 2012). Miller and Vanhoosie (2008) described savings as an abandonment of consumption. When someone is not spending all the income earned during a given period.
According to them, what is part of what is gained now is left for future use is referred to as savings. In the economic context, savings have been defined as the residual income after deducting current consumption over a period of time. In Indian context it has been studied and found that the savings rate rises with both the level and the rate of growth of disposable income and magnitude of the impact of the former is smaller than that of the later. and real interest rate on deposits has a positive impact but the magnitude of the impact is modest. (Athukorala Prema Chandra, Kunal Sen, 2001).

In economic theories it is stated that saving as a part of disposable income that is not consumed. In the Keynesian economics savings have been defined as what a person has left over when the cost of his or her consumer expenditure is subtracted from the amount of disposable income earned in a given period of time. In a simple definition Ahmed (2007) argued that the saving would be the result of careful management of income and expenditure therefore that is something left to be put aside for future use. In most economics theories it is considered that the saving as a will power and foresight, saving as a result of ability to saving and saving as a self-controlling strategies and mental accounting. Further in Economics there are various theories concerning saving of people such as relative income theory (Duesenberry, 1949), Permanent income theory (Friedman, 1957) \& the life cycle theory (Modigliani, 1954). According to Duesenberry in his relative income theory explains the amount of spending on consumption does not depend on the income of individuals instead it depends on the standard of living in a particular environment individuals are living. Friedman in his theory of permanent income assumes that amount of spending is characterized by a permanent level dependent on expected standard of living of person's entire life time. On the other hand, in the life cycle theory assumes that individuals' savings are depends on as per to the life cycle 
stages or the age structure of the population of a country. That theory further explains that younger people with low income tend to take loans and matured \& stable people with higher income tend to save for future security when they become again lower income earners with higher level of other commitments. (C. Joanna, et al., 2015). These can be identified as saving motives and these motive remain unchanged throughout entire life time. J. Meynard Keynes, in 1936 has further explained about eight motives as why do people save? In his Keynesian theory (Browning, M., \& Lusardi, A. 1996). However, the research paid less attention to the development of the financial situation and consequently the psychological explanation began to emerge.

\section{Factors affecting to Savings Intention}

\section{Personal Income}

Most studies have examined data on income level and saving behavior from the previous period worldwide. The income can be identified as the flow of cash or cash equivalents received from work (wage or salary), Capital (interest or profit) or land (rent). In economics the maximum amount an individual can spend during a period without being any worse off. Personal income determines about the capacity of the savings. Many previous studies have shown a positive relationship between levels of personal income and people's savings (Nyhus Katrine Ellen, 2002), Saving of higher income group will decrease comparatively more than other groups specifying that higher income people having higher income always prefer their children to study from well known institutes of their areas; they will forego their more saving as compared to lower or middle income groups. Keynes (1939), argued that psychological features and patterns would change very slowly in a population and that current income is an important measure of income. The following are some definitions of personal income.
- Personal income is the amount of money collectively received by the inhabitants of a country.

- From employment, dividends and distributions paid by investments, rents derived from property ownership and profit sharing from business.

- Personal incomes generally subject to taxation.

In economists' view of point, the term called personal income is referring to the total compensation received by an individual where sometimes refers as individual income and in other word gross income. Personal income affects consumption more than anything else. The level of income will determine a person's level of consumption.

\section{Financial Literacy}

The financial literacy is defined as a set of ability to read, analyze, understand, manage and communicate the terms and mainly basic economic concepts which are used in effective personal financial decision making.A Study has been done by Joan C. Koonce et al in 2008 participating school students have found that high school students with more financial experience had higher savings rates than those with less experience, This has also been defined as sufficient knowledge of personal finance facts and terms for successful personal financial management. The financial literacy includes the ability to balance bank account, budgeting, saving for the future and learning necessary strategies to manage debt (Bahmar, 2012). According to Kumari (2017; 2020a; $2020 \mathrm{~b}$ ), financial literacy is the combination of few dimensions as: financial awareness, financial knowledge, financial attitudes, financial skills and financial behavior. Kumari, and Ferdous in 2019, examined that, the mediating effect of financial inclusion on financial literacy and women's economic empowerment. Financial literacy was considering as a significant variable among 
rural poor women in Sri Lanka. Further, Kumari, Ferdous and Khalida in 2020, jointly examined that the impact of financial literacy on women's economic empowerment in developing countries as an another important study to examined about the financial literacy. Financial literacy helps individuals to improve their level of understanding of financial matters which enables them to process financial information and make informed decisions about personal finance (Bhushan, \& Medury, 2013). A research done in france it was found that some sub populations are less financially literate than others, women, young and old people as well as less-educated people are more likely to face difficulties when dealing with fundamental financial concepts such as risk diversification, inflation and interest compounding (Arrondel et al., 2013).

Financial literacy has five dimensions, such as financial knowledge, financial communication, the ability to use financial knowledge in decision-making, real use of financial instruments (financial behavior) and a sense of financial confidence. For each dimension, measures must address at least four financial areas such as budgeting, saving, credit and investment. Understanding financial concepts, individuals will be able to be selfsufficient in financial knowledge and skills effectively and can manage personal financial behavior in order to invest or save their income achieving financial stability. There are some features of financial literacy, such as effective financial planning, proper debt management, accurate interest calculations, and an understanding of the time value of money. This financial education will enhance the skills needed to effectively monitor expenditures, pay down debt and adequately plan for retirement .This also improves poor financial decision-making in people's most effective financial decision-making. A research conducted by the OECD in 2005 they examined the level of financial literacy in 12 major countries of the world including UK, USA, European countries, Japan and Australia and the research concluded that the level of financial literacy for most of the respondents is very low (Badshah et al., 2014). Lack of proper financial literacy would result, rising individual debt levels with overuse of credit cards, using personal loans for consumption and undertaking over-optimistic home-loan obligations, irresponsible overspending on consumption, foolish commitment to get-richquick schemes, making unwise high risk investments inconsistent with required capital stability and entering inappropriate vehicleleasing contracts, among others (Beal, \& Delpachitra, 2003).

\section{Parental Socialization}

Parents are considered as first teachers for their children. Mostly better educated parents are more likely to give a better education for their children. Parental socialization wills management. The family is a very important agent of socialization for both factual and emotional uses of money (Danes, 1994). Researchers have investigated this concept determinant of saving behavior among the university students in Malaysia and have found that parents are influencing their economic behavior.

Since childhood, parents have worked to strengthen the behaviour of their children by providing them with a better orientation to protect external challenges in society's economy and culture. It is possible to distinguish two types of parents. First type parents are looking to children behavior and protect them by using parents' knowledge. The second type parents are teaching and guiding their children to protect by themselves using children own knowledge for externalities. Here it is important for parents have the children who are well educated and have better knowledge on financial management, economic matters social matters etc.

Those who have knowledge by their parents particularly trade and market 
conditions interest rates investments procedures etc can manage properly their life cycle. When there are different teaching methods by their parents everyone can address their financial issues in future.

Socialization is the act of behaving in accordance with the norms of a culture or society called socialization. In other words, getting out and meeting people or dating peers. Collective socialization theories are usually based on psychological literature on parental supervision and role models, as well as sociological literature on supervision and isolation. Socialization is considered an important area of psychology and is directly related to psychology and socialization factors. At the same time, this field includes various theories, concepts and approaches. For instance, the theory of evolution was created as a thought of socialization theories since 1970.

\section{Peer Influence}

Peer influence means the direct influence on people by peers or the effect on an individual who gets encourage to follow their peers by changing their attitudes, values or behaviors to conform to those of the influencing group or individual. The influencing effect would be positive and negative effect or both. Peer influence will be directly affecting to individuals' savings and financial decisions.

\section{Self- Control}

Self-control is defined as a component of inhibitory control. It is the ability to regulate one's emotions, thoughts and behavior in the face of temptations and impulses. Self-control is also defined as a cognitive process that is necessary for regulating one's behavior in order to achieve specific goals. In the short term over use of self-control will lead to depletion and in the long term it can strengthen and improve over time. Self-control is the ability to identify and regulate one's emotions and desires. It is characterized by the exertion of will, self-discipline and ability to delay gratification. For an operational definition of self-control TOTE model (Test, Operate, Test, Exist) of self-regulation will be a basis for this definition. Some have found that Attitudes, subjective norms, and perceived behavioral control are shown to be related to appropriate sets of salient behavioral, normative, and control beliefs about the behavior, but the exact nature of these relations is still uncertain. (Ajzen, 1991).

\section{Financial Benefits}

Financial benefits refer to, in relation to an asset, any direct or indirect benefit in any number of terms (or convertible in any number of terms) attributable to or accrued to that asset. In other words, it is a benefit in the form of money, property, commercial interest or anything that is primarily economic gain.

Financial rewards are also very important for those who support engagement with an institution or organization inside and outside the organization. A well-designed reward system will be a key success factor for any institution to its employees as well as its customers. The maintenance of a reward system will strengthen the client base and their level of performance within the organization. When it comes as financial rewards these will be financial gain such as interest, pay, bonus etc. However rewards and benefits are three types such as extrinsic, intrinsic and social rewards. Extrinsic benefits are considered as physical benefits provide by organization such as pay bonus fringe benefits etc. and also intrinsic rewards refer to the rewards come from the content of the job itself. For an example role clarity, autonomy and training etc. Social rewards are arise from interaction with other people on the job and may include supportive relationship.

\section{Gender}

Gender generally and broadly we accept as male or female or in any other sexual status 
of a person. The gender is the range of characteristics pertaining to and differentiating between masculinity and femininity. Depending on this context, these characteristics may be inclusion of biological sex (state of being male female or an intersex variation). Sex based social strangers and gender identity. On a global scale, some societies have specific genders in addition to men and women, such as in South Asia, which is known as the third gender. Some researches have done their studies to evaluate individuals' general knowledge on budgeting, used of automated teller machine, time value of money, account types, Cheque handling and insurance based on gender disparity (Adam et al., 2018). Further a Study has been done on the financial literacy level of women based on their financial knowledge, attitude and behaviour relating to their personal finances in india (Arora, A., 2016) and the there is a difference in the male and female knowledge on personal financial topics, (Chen, \& Volpe, 2002). As per the above critical review of the existing literature, researcher identified few factors as most influential factors (see the table 2) on savings intension among young customers in Sri Lanka.

Table 2. Factors affecting on Customer saving intension

\begin{tabular}{|c|c|c|}
\hline Factors & Author/s & Description \\
\hline $\begin{array}{l}\text { Personal } \\
\text { Income }\end{array}$ & 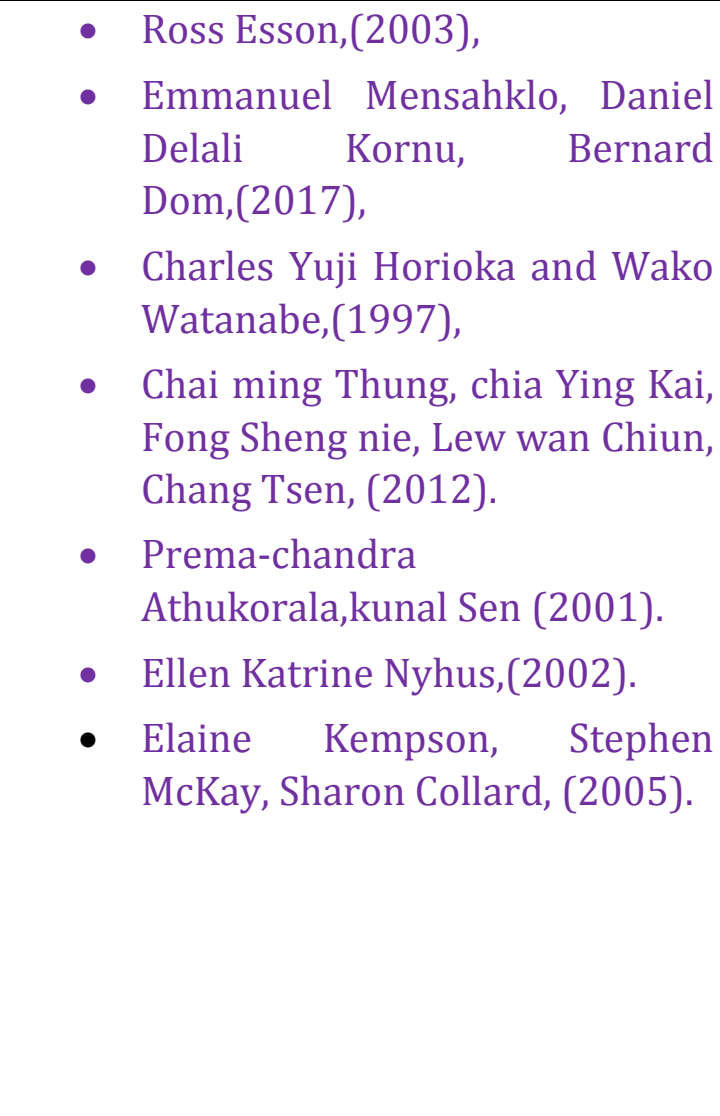 & $\begin{array}{l}\text { Savings and Savers: An analysis of } \\
\text { saving behavior among cape town's } \\
\text { poor. } \\
\text { An Empirical Analysis of the } \\
\text { Determinants of Saving Behaviour by } \\
\text { Households in Ho, Ghana: A Case Study } \\
\text { of Ho Municipality, An Individual Level } \\
\text { Analysis. } \\
\text { Why Do People Save? A Micro-Analysis } \\
\text { of Motives for Household Saving in } \\
\text { Japan. } \\
\text { Determinants of Saving Behavior } \\
\text { among the University Students in } \\
\text { Malaysia. } \\
\text { The determinants of Privet saving in } \\
\text { India. } \\
\text { Psychological determinants } \\
\text { Household saving Behavior. } \\
\text { Incentives to save: Encouraging saving } \\
\text { among low-income households. }\end{array}$ \\
\hline
\end{tabular}




\begin{tabular}{|c|c|c|}
\hline $\begin{array}{l}\text { Financial } \\
\text { Literacy }\end{array}$ & $\begin{array}{l}\text { - Chai ming Thung, chia Ying Kai, } \\
\text { Fong Sheng nie, Lew wan } \\
\text { Chiun,Chang Tsen, (2012), } \\
\text { - Joan C. Koonce, Yoko Mimura, } \\
\text { Teresa A. Mauldin, A. Michael } \\
\text { Rupured, and Jenny Jordan } \\
\text { (2008). } \\
\text { - Umi Widyastuti, Usep Suhud, Ati } \\
\text { Sumiati (2016) }\end{array}$ & $\begin{array}{l}\text { Determinants of Saving Behavior } \\
\text { among the University Students in } \\
\text { Malaysia. } \\
\text { Financial Information: Is It Related to } \\
\text { Savings and Investing Knowledge And } \\
\text { Financial Behavior of Teenagers? } \\
\text { The Impact of Financial Literacy on } \\
\text { Student Teachers' Saving Intention and } \\
\text { Saving Behaviour. }\end{array}$ \\
\hline $\begin{array}{l}\text { Parental } \\
\text { Socialization }\end{array}$ & $\begin{array}{l}\text { - Chai ming Thung, chia Ying Kai, } \\
\text { Fong Sheng nie, Lew wan Chiun, } \\
\text { Chang Tsen, (2012). } \\
\text { - Jeetendra Dongol, Saru } \\
\text { Maharjan (2018). }\end{array}$ & $\begin{array}{l}\text { Determinants of Saving Behavior } \\
\text { among the University Students in } \\
\text { Malaysia. } \\
\text { Parental and Peer Influence on the } \\
\text { Saving Behavior of the Youth. }\end{array}$ \\
\hline Peer influence & $\begin{array}{l}\text { - Chai ming Thung, chia Ying } \\
\text { Kai,Fong Sheng nie, Lew wan } \\
\text { Chiun, Chang Tsen, (2012), } \\
\text { - Jeetendra Dongol, Saru } \\
\text { Maharjan (2018). }\end{array}$ & $\begin{array}{l}\text { Determinants of Saving Behavior } \\
\text { among the University Students in } \\
\text { Malaysia. } \\
\text { Parental and Peer Influence on the } \\
\text { Saving Behavior of the Youth. }\end{array}$ \\
\hline Self-Control & $\begin{array}{l}\text { - Chai ming Thung,chia Ying Kai, } \\
\text { Fong Sheng nie, Lew wan Chiun, } \\
\text { Chang Tsen, (2012). } \\
\text { - Jhon Bashears, James J Choi, } \\
\text { Christopher Harris, David } \\
\text { Laibson, Brigitte C Madrin } \\
\text { (2015) }\end{array}$ & $\begin{array}{l}\text { Determinants of Saving Behavior } \\
\text { among the University Students in } \\
\text { Malaysia. } \\
\text { Self control and commitment: can } \\
\text { decreasing the liquidity of a saving } \\
\text { account increase deposits? }\end{array}$ \\
\hline $\begin{array}{l}\text { Financial } \\
\text { Benefits }\end{array}$ & 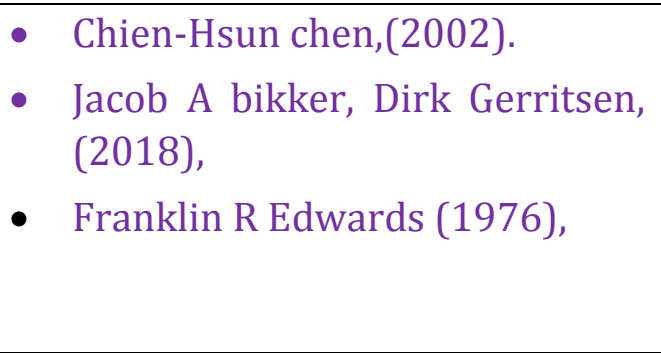 & $\begin{array}{l}\text { Interest rates,Savings and Income in the } \\
\text { Chinese Economy. } \\
\text { Determinants of Interest rates on time } \\
\text { deposits and savings accounts, Macro } \\
\text { factors, bank risk and account features. } \\
\text { Interest rates on Savings. }\end{array}$ \\
\hline Gender & $\begin{array}{l}\text { - Joan C. Koonce, Yoko Mimura, } \\
\text { Teresa A. Mauldin, A. Michael } \\
\text { Rupured, and Jenny Jordan } \\
\text { (2008) } \\
\text { - Patti J. Fisher, Catherine P. } \\
\text { Montalto, (2009) }\end{array}$ & $\begin{array}{l}\text { Financial Information: Is It Related to } \\
\text { Savings and Investing Knowledge And } \\
\text { Financial Behavior of Teenagers?. } \\
\text { Effect of Saving motives and horizon on } \\
\text { saving behavior. }\end{array}$ \\
\hline
\end{tabular}

Source: Researcher constructed based on the previous literature 


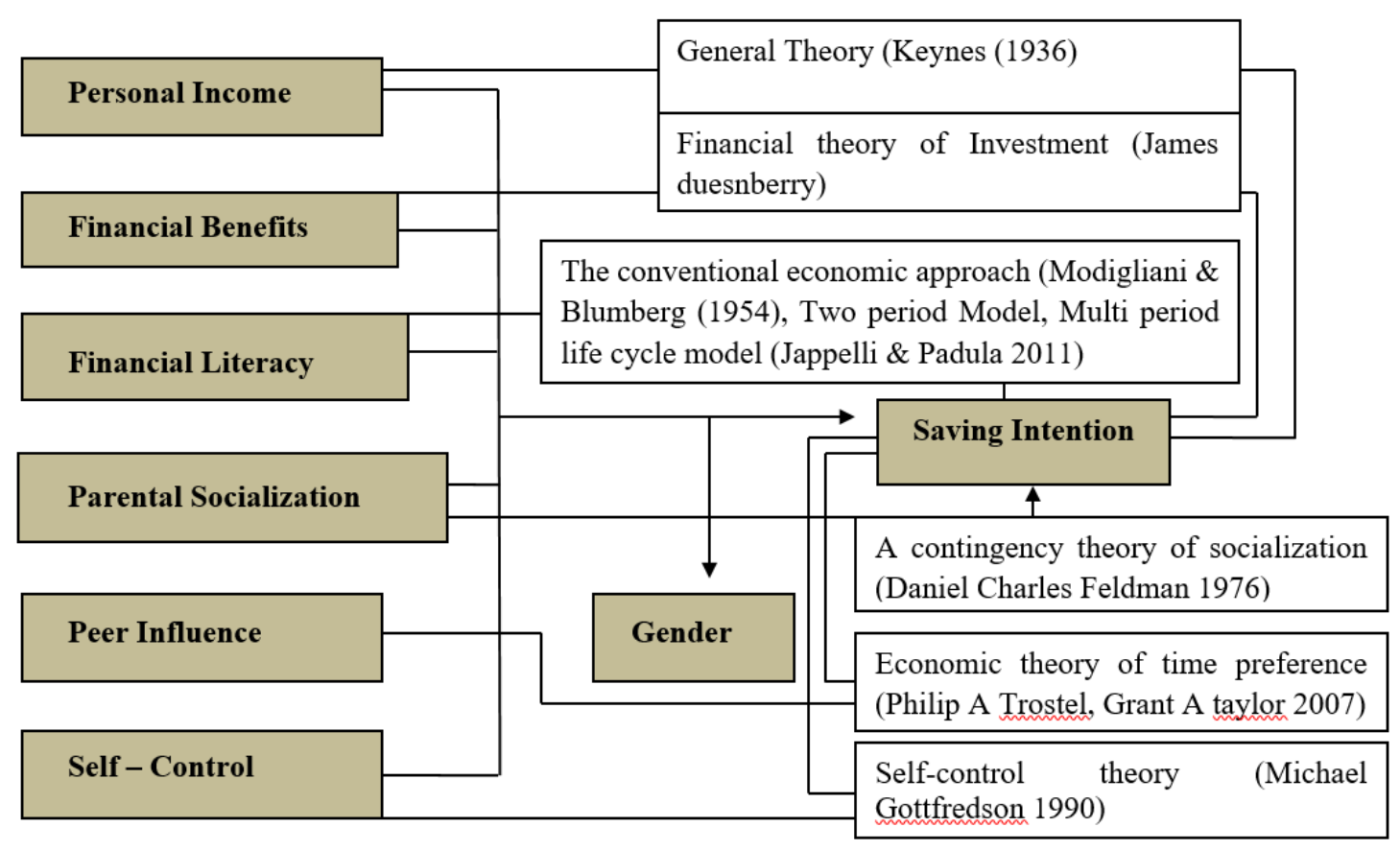

Figure 2. Theoretical model

Source: Researcher constructed based on the theoretical and empirical background.

The factors identified above are mostly influenced individual's savings behavior, accordingly researcher has created the theoretical model to study the impact of these factors with the saving intention of young customers in Sri Lanka. Previous studies have been proved that there are significant positive and also negative relationships with these factors.

\section{Theoretical Model}

Based on the above theoretical and empirical evidences researcher formulated the theoretical model for the study as shown in the figure 2 .

\section{Conclusion}

The literature arranges in this paper was mainly focused on the impact with factors and the young customers saving intention. In this process, the study focusing on the young aged customers who are between 18 to 30 years in the central region of the country. According to the critical literature review given in this paper, all the factors have direct impact on the saving intention of individuals as mostly determined by the previous studies. It is noted that that the younger customer base is considerably lower in licensed specialized banks than in other commercial banks in the country. Focusing on younger generation it is evident that they are dealing with these financial institutions under above discussed factors and influencing these factors to their saving intention in different perspectives. Other than the factors study discussed there are many theories and studies have proved that personal income and saving intention of people has a high impact and financial literacy is also having a major effect as per to the previous studies on the saving intension of individuals. It is more important to investigate on the young customers' savings intention in banks like licensed specialized banks to take financial decisions and make policies to fill the gaps and lapses in those banks as well as in an economy where we can identify major affecting factors and make fruitful financial decisions. Researcher could suggest form the future researchers, more improvement and development on the selected factors to find out further more relationships with saving of younger people and could be able to make 
decisions \& policies appropriately in the relevant environment.

\section{References}

Adam, A.M., Boadu, M.O., Frimpong, S., (2018). Does Gender Disparity in Financial Literacy Still Persist After Retirement? Evidence from Ghana, International Journal of Social Economics, 45(1), 18-28. https://doi.org/10.1108/IJSE-06-2016-0159

Ahmed, M.S (2007).Management in living for senior secondary schools (2nd ed.) Ghana,Kumasi:Bayoba Graphics Limited.

Aggarwal, N., (2014). Financial Literacy among farmers: Empirical evidence from Punjab. Pacific business review international, 6 (7), 36-42.

Ajzen, I., (1991). The theory of planned behaviour. Organizational Behaviour and Human Decision Processes, 50 (2), 179-211. https://doi.org/10.1016/0749-5978(91)90020-T.

Arora, A. (2016). Assessment of Financial Literacy among working Indian Women, Accessed form https://www.researchgate.net/publication/298790053

Arrondel, L., Debbich M., Savignac, F., (2013) Financial literacy and financial planning in France. Numeracy 6(2), 1-17. http://dx.doi.org/10.5038/1936-4660.6.2.8

Athukorala, P.C., Sen, K. (2004). The determinants of private saving in India. World Development, 32(3), 491-503. https://doi.org/10.1016/j.worlddev.2003.07.008.

Badshah, W., Hakam, U., Khan, A.S., Saud, S., (2014). Factors Effecting short-term investment intensions of stock investors in Pakistan. Management and Administrative Sciences Review, 3(3), 464-469.

Bahmar, Z. (2012). Investigating the relationship between financial literacy and prosperity and the determining association with demographic variables,Indian journals of fundamental and applied research, (pp.1143-11542)

Beal, D.J., Delpachitra, S.B., (2003). Financial literacy among Australian university students. Economic Papers: A Journal of Applied Economics and Policy, 22(1), 65-78.

Bhushan, P., Medury, Y., (2013). Financial literacy and its determinants, International Journal of Engineering, Business and Enterprise Applications (IJEBEA), 4(2), 155- 160. http://hdl.handle.net/123456789/9603.

Bonga, W.G., Mlambo, N., (2016) Financial Literacy Improvement Among Women in Developing Nations: A Case for Zimbabwe. Quest Journals, Journal of Research in Business and Management, 4(5), 22-31.

Browning, M., Lusardi, A., (1996). Household saving: Micro theories and micro facts. Journal of Economic Literature, 34, 1797-1855.

Central Bank of Sri Lanka (CBSL), (2019). Annual Report of the Monetary Board to the Hon. Minister of finance, (Volume II), Colombo, Sri lanka. Accessed from: https://www.cbsl.gov.lk/en/publications/economic-and-financial-reports/annualreports/annual-report-2019

Chen, H., Volpe, R.P., (2002). Gender Differences in Personal Financial Literacy Among College Students. Financial Services Review, 11(3), 289-307. 
Chudzian Joanna, Mikołajczak Paulina Anioła, Pataraia Larisa,(2015) Motives and attitudes for saving among young georgians, Chudzian, Economics and Sociology, 8(1) 165-188. https://doi.org/10.14254/2071- 789X.2015/8-1/13

Danes, S.M., (1994). Parental perceptions of children's financial socialization. Journal of Financial Counseling and Planning, 5, 127-149.

Duesenberry, J.S. (1949) Income-Consumption Relations and Their Implications. In: Metzler, L., et al., Income, Employment and Public Policy, W.W. Norton \& Company, Inc., New York.

Emmanuel Mensahkla, Daniel Delali Kornu, Bernard Dom, (2017), An Empirical Analysis of the Determinants of Saving Behaviour by Households in Ho, Ghana: A Case Study of Ho Municipality, An Individual Level Analysis, Journal of Economics and Sustainable Development, 8(6) 7-17.

Friedman, M., (1956) A Theory of the consumption Function, Princeton: Princeton university press, New Jersey.

Hart, H.L.A. (1994), The Concept of Law, second edition, Oxford University Press Inc, New York.

Joan C. Koonce, Yoko Mimura, Teresa A. Mauldin, A. Michael Rupured, and Jenny Jordan, (2008), Financial Information: Is It Related to Savings and Investing Knowledge and Financial Behavior of Teenagers?:Journal of Financial Counseling and Planning, 19(2),

Kumari, D.A.T., (2012a), Financial intermediation development: A contributing factor to economic growth in Sri Lanka (With special reference to post liberalization of Financial sector in Sri Lanka, Wayamba Journal of Management, $03(1), 56-74$.

Kumari, D.A.T., (2012b) Influential factors of aggregate savings in Sri Lanka: An empirical study, Journal of Insurance, 2(1), 57 -74.

Kumari, D.A.T., (2013), Factors Influencing the Adoption of Internet Banking: An empirical study in the context of commercial banks in Sri Lanka. Sri Lanka Journal of Banking and Finance, 1(2), 78-90.

Kumari, D.A.T., (2017), Financial Literacy: An Essential Tool for Empowerment of Women through Financial Inclusion - Literature Review Equality and Management, Faculty of Economics and Management, University of Szczecin, Poland.

Kumari, D.A.T., (2020a).The Impact of Financial Literacy on Investment Decisions: With Special Reference to Undergraduates in Western Province, Sri Lanka. Asian Journal of Contemporary Education, 4, 2, 110-126.

Kumari, D.A.T., (2020b). Determinants of Financial Literacy: with Special Reference to Consumers in Financial Service Industry. Sri Lanka Journal of Marketing, University of Kelaniya, 6 (2), 93-125.

Miller, R. \& VanHoose, D. (2008).Money,Banking and financial markets.Mason,Ohio:Cengage Learning.

Modigliani, F., Brumberg, R., (1954). Utility analysis and the consumption factor: A interpretation of the data. In: K. Kurihara, Post-Keynesian economics, Rutgers University Press, New Brunswick, NJ. 
Vol 4 Iss 2 Year $2021 \quad$ W.M.K.T. Dharmarathna \& D.A.T. Kumari /2021

Nyhus, K.E., (2002), Psychological determinents of household savings behaviour, Doctoral Dissertation, Norges handelshøyskole. Institutt for strategi og ledelse. Accessed form: https://openaccess.nhh.no/nhh-xmlui/handle/11250/164358

Thung, C.M., Kai, C.Y., Nie, F.S., Chiun, L.W., Tsen, T.C, (2012), Determinents of savings behaviour among the university students in Malaysia, A research project submitted in partial fulfillment of the requirement for the degree of B ,May 2012.RMP15T1G3.

Widyastuti, U., Suhud, U., Sumiati, A., (2016) The Impact of Financial Literacy on Student Teachers' Saving Intention and Saving Behaviour, Mediterranean Journal of Social Sciences, 7 (6), 41 48. http://dx.doi.org/10.5901/mjss.2016.v7n6p41

Does this article screened for similarity: YES

Funding: No funding was received for conducting this study

Conflict of Interest: The authors have no conflicts of interest to declare that they are relevant to the content of this article.

About the License

(C) The author(s) 2021. The text of this article is open access and licensed under a Creative Commons Attribution 4.0 International License 